\title{
Differences in the Chemical Composition of the Particulate Phase of Inhaled and Exhaled Cigarette Mainstream Smoke*
}

\author{
by \\ Serban C. Moldoveanu ${ }^{l}$ and F. Kelley St.Charles ${ }^{2}$ \\ ${ }^{I}$ R.J. Reynolds Tobacco Co., 950 Reynolds Boulevard, Winston-Salem, NC 27105, USA \\ ${ }^{2}$ Consultant, 112 Raven Avenue, Perry, GA 31069, USA
}

\section{SUMMARY}

In this study, a comparison between the chemical composition of the particulate-phase of exhaled smoke and that of smoke generated with a smoking machine has been performed. For this purpose, eight human subjects smoked a common Lights (10.6 mg 'tar/cig) commercial cigarette and the exhaled particulate-phase smoke from three cigarettes was collected on Cambridge pads for each smoker. The smoke collection from the human subjects was vacuum assisted. The cigarette butts from the smokers were collected and analyzed for nicotine. The machine smoking was performed with a Borgwaldt RM20 CSR smoking machine working under conditions recommended by the U.S. Federal Trade Commission (FTC). The nicotine levels for the cigarette butts from the smokers were used to normalize the level of exhaled smoke condensate to that of the FTC smoking conditions. The smoke condensates from exhaled smoke as well as that from the machine smoking were analyzed by a gas chromatographic technique with mass spectral peak identification. The retention efficiency for 160 compounds was calculated from the ratio of the compound peak areas in the exhaled smoke (normalized by the corresponding butt nicotine level) vs. the areas of the corresponding peaks from the chromatogram of the smoke generated by the smoking machine. In the calculation of the results, it was assumed that the composition of mainstream smoke remains practically constant at different smoking regimes. All compounds found in the machine-generated smoke were also present in the exhaled smoke, but at different levels. About one third of the compounds were retained more than $66 \%$ by the smoker. Another third of the compounds were retained between $33 \%$ and $66 \%$, and the rest of the compounds were retained very little from the mainstream particulate-phase of the cigarette smoke. The compounds retained more than $66 \%$ were in general compounds with lower molecular weight and with higher water solubility, which eluted first from a 5\% phenyl dimethyl-polysiloxane (DB-5MS) chromatographic column. The compounds retained less than $33 \%$ from smoke were those with higher molecular weights and boiling points, which had longer elution times from the chromatographic column. These compounds consisted mainly of long-chain hydrocarbons (saturated or squalene type) and phytosteroltype compounds. The compounds retained between $33 \%$ and $66 \%$ had intermediate chromatographic retention times. No attempt was made to evaluate or identify new compounds formed in the exhaled smoke. The results were obtained from a limited number of subjects, but among these the retentions for individual compounds did not show large differences, indicating that the retention process is not very different for the subjects evaluated. An attempt was made to verify whether or not the retention of compounds by the smoker is analogous to a distribution process. Only weak correlations were obtained between the human retention and octanol/water partition coefficients or between the human retention and the chromatographic retention times of individual compounds. [Beitr. Tabakforsch. Int. 2006 (22) 290-302]

\section{ZUSAMMENFASSUNG}

Diese Untersuchung vergleicht die chemische Zusammensetzung der Partikelphase von exhaliertem Rauch mit der von Rauch, der mit einer Rauchmaschine erzeugt wurde. Hierfür rauchten acht Testpersonen handelsübliche LightZigaretten (10,6 mg Kondensat), wobei die Partikelphase des exhalierten Rauches von insgesamt drei verschiedenen Zigarettenmarken auf Cambridgefiltern gesammelt wurde. Die Sammlung dieser Rauchproben erfolgte vakuumunterstützt. Die Zigarettenstummel der Raucher wurden gesammelt und auf ihren Nikotingehalt untersucht. Das maschinelle Abrauchen erfolgte mit einer Borgwaldt RM20 
CSR Rauchmaschine gemäß der Abrauchnormen der U.S. Federal Trade Commission (FTC). Auf der Basis des Nikotingehalts der von den Rauchern erhaltenen Zigarettenstummel wurde die Menge an exhaliertem Rauchkondensat auf FTC-Bedingungen standardisiert. Das Rauchkondensat des exhalierten und des von der Rauchmaschine erhalten Rauches wurde mittels Gaschromatographie und Massenspektrometrie analysiert. Die Retentionseffizienz für 160 Verbindungen wurde aus dem Verhältnis der Peakflächen der einzelnen Verbindungen im exhalierten Rauch (standardisiert auf den entsprechenden Nikotingehalt im Stummel) zu den entsprechenden Peakflächen im Chromatrogramm des Rauchmaschinen-genierierten Rauches berechnet. Bei der Berechnung der Ergebnisse wurde angenommen, dass die Zusammensetzung des Hauptstromrauchs unter verschiedenen Abrauchbedingungen praktisch konstant bleibt. Alle im Rauchmaschinen-generierten Rauch gefundenen Verbindungen befanden sich ebenfalls im exhalierten Rauch, lagen jedoch in unterschiedlichen Konzentrationen vor. Ungefähr ein Drittel der Verbindungen wurde zu mehr als $66 \%$ vom Raucher reteniert. Bei einem weiteren Drittel der Verbindungen wurden zwischen $33 \%$ und $66 \%$ reteniert, der Rest der Verbindungen wurde zu einem geringen Anteil aus der Partikelphase des Hauptstromrauchs von Zigaretten reteniert. Die Verbindungen, die zu mehr als $66 \%$ aus dem Rauch reteniert wurden, waren hauptsächlich Verbindungen mit niedrigerem Molekulargewicht und höherer Wasserlöslichkeit, die zuerst von der Säule (DB-5MS) eluiert wurden. Die Verbindungen, die zu weniger als $33 \%$ aus dem Rauch reteniert wurden, besaßen ein höheres Molekulargewicht und höhere Siedepunkte und auch längere chromatographische Elutionszeiten. Diese Verbindungen bestanden vorwiegend aus langkettigen Kohlenwasserstoffen (gesättigte oder Squalenähnliche Verbindungen) und Phytostyrol-ähnlichen Verbindungen. Die chromatographischen Retentionszeiten der Verbindungen, die zu $33 \%$ bis $66 \%$ reteniert wurden, lagen dazwischen. Es wurde nicht versucht, neue Verbindungen, die im exhalierten Rauch gebildet wurden, zu charakterisieren oder zu identifizieren. Die Ergebnisse wurden mit einer begrenzten Zahl von Rauchern erhalten, bei denen die individuellen Retentionen einzelner Substanzen keine großen Unterschiede aufwiesen, was darauf hindeutet, dass bei den untersuchten Rauchern die Retention von Substanzen nicht sehr verschieden war. Es wurde der Versuch unternommen zu verifizieren, ob die Retention von Verbindungen beim Raucher sich analog zu einem Verteilungsprozess verhält. Es wurden nur schwache Korrelationen zwischen der Retention von Substanzen im menschlichen Organismus und den Oktanol/Wasser-Verteilungskoeffizienten oder den chromatographischen Retentionszeiten einzelner Verbindungen gefunden. [Beitr. Tabakforsch. Int. 22 (2006) 290-302]

\section{RESUME}

Cette étude compare la composition chimique de la phase particulaire exhalée par le fumeur avec celle de la fumée générée par une machine à fumer. Pour cela, huit fumeurs ont fumé une cigarette légère habituelle et la phase particulaire exhalée de trois types de cigarette de chacun des fumeurs a été recueillie sur des filtres Cambridge. La collecte de fumée des fumeurs humains a été effectuée par des dispositifs sous vide. Les mégots des cigarettes obtenus par les fumeurs ont été retirés et dosés pour leur teneur en nicotine. Le fumage a été réalisé sur machine à fumer Borgwaldt RM20 CSR en conditions normalisées de la Federal Trade Commission (FTC). Le rendement du condensat de la fumée exhalée a été normalisé selon les conditions FTC à la base de la teneur en nicotine des mégots retirés des fumeurs. Le condensat de la fumée exhalée et celui obtenu sur machine à fumer ont été analysés par chromatographie en phase gazeuse et spectrométrie de masse. L'efficacité de rétention de 160 composants a été calculée en fonction du ratio entre la surface des pics des composés de la fumée exhalée (normalisée en fonction de la teneur en nicotine correspondante dans le mégot) et la surface des pics correspondants de la fumée générée sur machine à fumer. Dans le calcul des résultats il a été supposé que la composition de la fumée principale reste constante sous les différents régimes de fumage. Tous les composés trouvés dans la fumée générée sur machine ont également été trouvés dans la fumée exhalée, mais sont présents en teneurs différentes. Un tiers environ des composés a été retenu de plus de $66 \%$ par le fumeur. Un autre tiers des composés a été retenu de $33 \%$ à $66 \%$ et les autres composés ont été retenus de façon réduite à partir de la phase particulaire de la fumée de cigarette. Les composés retenus de plus de $66 \%$ sont en général des composés de faible poids moléculaire et solubilité dans l'eau élevée, éluant le premier de la colonne chromatographique avec du phényldiméthyl-polysiloxane (DB-5MS). Les composés retenus de moins de $33 \%$ à partir de la fumée sont des composants de poids moléculaires et de points d'ébullition plus élevés ayant une élution de la colonne moins rapide. Ces composés sont surtout des hydrocarbures à longue chaîne (saturés ou de type squalène) et des composés de type phytostyrol. Les composés retenus de $33 \%$ à $66 \%$ ont un temps de rétention de la colonne intermédiaire. L'évaluation et l'identification des composés nouvellement formés dans la fumée exhalée n'ont pas été considérées dans l'étude. Les résultats ont été obtenus à partir d'un nombre limité de fumeurs, mais parmi ceux-ci il n'existent pas de grandes différences dans les temps de rétention des composés particuliers. Ceci indique que le processus de rétention ne diffère pas de façon importante chez les fumeurs examinés. Il a été également étudié si la rétention des composés par les fumeurs se trouve en analogie avec un processus de distribution. De faibles corrélations ont été observées entre la rétention humaine et les coefficients de partage entre le décanol et l'eau ou entre la rétention humaine et les temps de rétention chromatographique des composés particuliers. [Beitr. Tabakforsch. Int. 22 (2006) 290-302]

\section{INTRODUCTION}

Although the interest in the retention by the smoker of cigarette smoke constituents is about 100 years old (1), most of this interest has been focused on nicotine (2-7) and on whole particulate matter (8-14). As reported in an excellent recent review (15), very few published papers evaluated other individual compounds in exhaled smoke. 


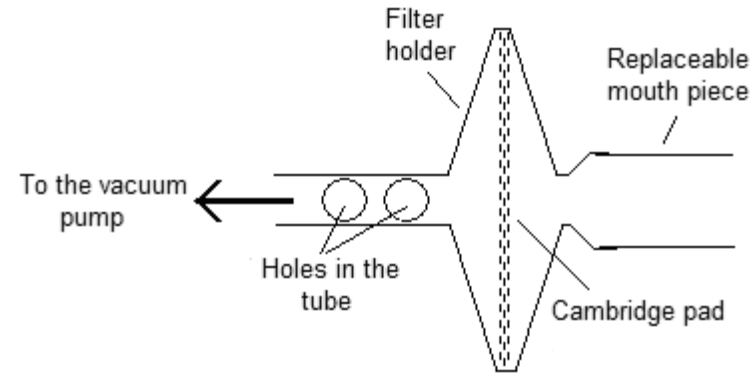

Figure 1. Schematic drawing of the device used for the collection of exhaled mainstream cigarette smoke

An early paper published in 1909 included ammonia and pyridine (8). One study published in 1951 reported the retention of nicotine, pyridine, ammonia, and of several groups of compounds such as aldehydes plus ketones, phenols, neutral substances, etc. (16). Another study published in 1959 evaluated nitrogen oxides (17), two studies published in 1968 evaluated acetaldehyde, acetone, acetonitrile, isoprene, toluene, and CO $(13,14)$, and another study published in 1970 evaluated the retention of inhaled acetaldehyde (18). More recently, the retention of nitric oxide was revisited in a paper published in 1995 (19) and a study published in 1989 evaluated phenol, triacetin, propylene glycol, 3-hydroxypyridine, neophytadiene, hydroquinone and glycerol (20). Two other studies evaluated solanesol (together with nicotine) $(6,7)$. Several older British American Tobacco (BAT) internal studies give results on three carbonyl compounds, sum of phenols, isoprene, and coumarin (15). On the other hand, much more attention has been given to breath analysis (21-28). Differences in the content in the breath between smokers and nonsmokers were reported for compounds such as benzene, 1,3-butadiene, and 2,3-dimethylfuran (21), prostaglandin E2 (22), nitrite (23), and NO (24). A considerable number of other studies evaluated the composition of breath related to illnesses such as asthma and chronic obstructive pulmonary disease (COPD) (25-28). One paper indicating in the title the analysis of exhaled tobacco smoke (29) evaluated in fact simulated environmental tobacco smoke, as a sum of sidestream smoke and exhaled smoke. The study reported herein is intended to generate further information regarding the chemical composition of the particulate-phase of exhaled cigarette smoke. However, given that smoking behaviors, i.e. puff volume, puff frequency, potential vent-blocking, inhalation behaviors are known to vary for an individual smoker, as well as from one subject to the another, the study provides a limited 'snapshot' of exhaled cigarette smoke composition. Also, a larger variety of cigarette styles and specific analytical techniques for particular classes of compounds would be desirable for a more in-depth evaluation of the quantitative composition of exhaled cigarette smoke.

\section{EXPERIMENTAL}

\section{Smoke collection}

The first step in the analysis of exhaled smoke is the smoke collection from the human subjects. For this purpose, a simple device schematically shown in Figure 1 has been used. The device consists of a 92-mm Cambridge holder and pad having at one opening a replaceable mouth piece (Atlantic Medical Solutions, Charlotte, NC 28217), and at the other opening being connected to a diaphragm vacuum pump, which aspirates $2.2 \mathrm{~m}^{3} / \mathrm{h}$ (Vacuum brand GMBH, Wertheim, Germany). The tube connecting the pad holder to the pump has two large holes to the exterior, which can be covered with the fingers. When no smoke is exhaled, the holes in the tube to the vacuum pump are kept open such that air from the surrounding is aspirated by the pump without passing the Cambridge filter. During smoke exhalation, the smoker blows the smoke through the replaceable mouth piece. At the same time the holes in the tube are covered, such that the exhaled smoke is aspirated through the Cambridge pad. This allows the exhaled smoke to be collected on the pad, without additional strain on the smoker. Considerable strain would be necessary otherwise to overcome the flow resistance of the Cambridge pad. The device shown in Figure 1 was used by eight human subjects selected to smoke their preferred brand.

The cigarette was a filter Lights commercial product of $83 \mathrm{~mm}$, with American blend tobacco, $10.6 \mathrm{mg}$ target 'tar' ['tar' is defined as total particulate matter (TPM) minus water and nicotine]. The cigarette had $10.4 \mathrm{mg} \mathrm{CO}$ yield, $0.680 \mathrm{~g}$ tobacco, $27 \mathrm{~mm}$ filter, and $32 \%$ ventilation. Each subject smoked three cigarettes within one hour, and the exhaled smoke was collected. The smoking was performed in an environment familiar to the smoker (office) with as little as possible change from typical conditions. The cigarettes were previously conditioned under U.S. Federal Trade Commission (FTC) recommendations (30). The cigarette butts from the smokers were collected for nicotine analysis.

Mainstream particulate-phase smoke from ten cigarettes was also generated and collected with a Borgwaldt RM20 CSR smoking machine working under FTC type conditions (30) i.e. 35-mL puff volume, 2-sec puff duration, 60sec puff interval, calibration of the smoking machine to a specific 'tar' level. This machine-generated particulatephase smoke was used for the comparison with the exhaled smoke.

\section{Smoke analysis}

The particulate-phase from each pad was extracted with $25 \mathrm{~mL}$ acetonitrile, for $30 \mathrm{~min}$ on a mechanical shaker. The solution from the exhaled smoke was added in three aliquots of $5 \mathrm{~mL}$ onto $400 \mathrm{mg}$ Tenax $^{\circledR}$ (Tenax ${ }^{\circledR}$ GC, 35/60 mesh, Alltech, Deerfield, Illinois 60015), and gently evaporated after each addition. The evaporation was done at $40{ }^{\circ} \mathrm{C}$ under a current of nitrogen and lasted about 15 min for each aliquot. The study was done exclusively for particulate-phase compounds from smoke, and the very volatile compounds that may evaporate in these conditions were not of immediate interest. The solution from the machine-smoke pad was diluted in the ratio 3:10 to account for the difference in the number of cigarettes smoked by the human and by the machine and was further processed identically to the solution from the exhaled smoke. 
Table 1. GC-MS operating parameters ${ }^{a}$

\begin{tabular}{lccc}
\hline Parameter & Description & Parameter & Description \\
\hline GC column & DB-5MS & Carrier gas & Helium \\
Column dimensions & $60 \mathrm{~m}$ long, $0.32 \mathrm{~mm}$ i.d. & Flow mode & Constant flow \\
Film thickness & $0.50 \mathrm{~mm}$ & Flow rate & $1.1 \mathrm{~mL} / \mathrm{min}$ \\
Initial oven temperature & $37^{\circ} \mathrm{C}$ & Nominal initial pressure & $4.88 \mathrm{psi}$ \\
Initial time & $4.0 \mathrm{~min}$ & Purge valve off & $1 \mathrm{~min}$ \\
Oven ramp rate & $2{ }^{\circ} \mathrm{C} / \mathrm{mm}$ & Split flow & $20.0 \mathrm{~mL} / \mathrm{min}$ \\
Oven final first ramp & $60^{\circ} \mathrm{C}$ & $\mathrm{GC}$ outlet & $\mathrm{MSD}$ \\
Final time first ramp & $0 \mathrm{~min}$ & Outlet pressure & Vacuum \\
Oven ramp rate & $5{ }^{\circ} \mathrm{C} / \mathrm{mm}$ & MSD transfer line heater & $300^{\circ} \mathrm{C}$ \\
Oven final temperature & $320^{\circ} \mathrm{C}$ & lon source temperature & $230^{\circ} \mathrm{C}$ \\
Final time & $20 \mathrm{~min}$ & Quadrupole temperature & $150^{\circ} \mathrm{C}$ \\
Total run time & $87.5 \mathrm{~min}$ & MSD EM offset & $200 \mathrm{~V}$ \\
Inlet temperature & $310^{\circ} \mathrm{C}$ & MSD solvent delay & $2.0 \mathrm{~min}$ \\
Inlet mode & Splitless & MSD acquisition mode & $\mathrm{TIC}$ \\
Injection type & Mass range & $35 \mathrm{amu}-550 \mathrm{amu}$ \\
\hline
\end{tabular}

${ }^{\text {a }}$ Abbreviations: MSD = mass selective detector; MSD EM = mass selective detector electron multiplier; TIC = total ion chromatogram.

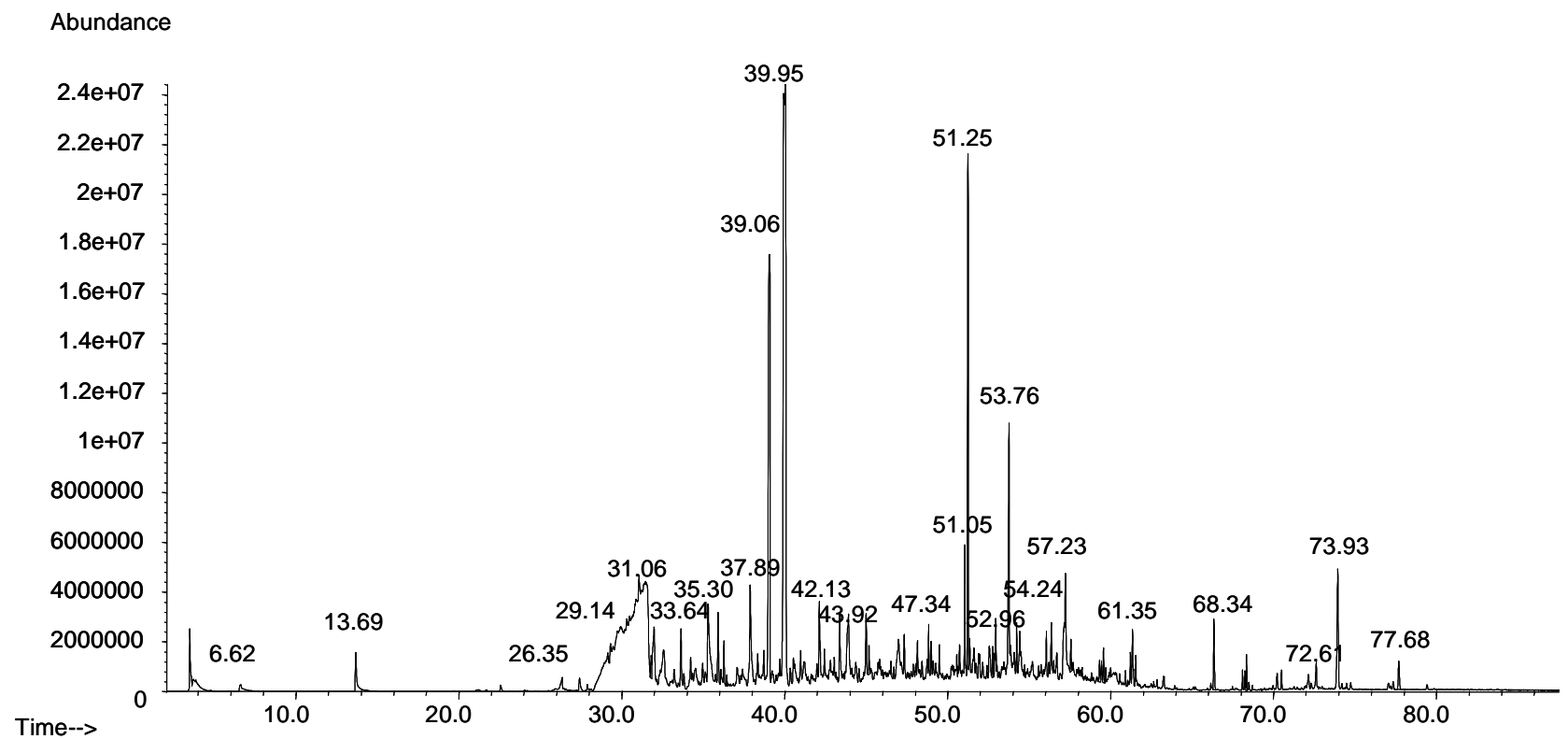

Figure 2. Chromatogram of the particulate-phase machine generated mainstream smoke

The smoke deposited on $5 \mathrm{mg}$ of Tenax ${ }^{\circledR}$ was desorbed at $340{ }^{\circ} \mathrm{C}$ for $30 \mathrm{sec}$ into a gas chromatographic-mass spectrometric (GC-MS) instrument for analysis. The desorption was done with a Pyroprobe 1000 insert with a platinum coil (CDS Analytical, Oxford, PA 19363) interfaced to the GC injection port. The GC-MS instrument was an Agilent 6890/5973 system (Agilent, Wilmington, Delaware 19808). The parameters for the analysis are given in Table 1.

The desorption procedure used to load the sample into the GC-MS system was preferred to the solution injection for several reasons. One reason was that the relatively high dilution of the pad extract did not produce chromatographic peaks of acceptable intensity. The use of $5 \mathrm{mg}$ Tenax ${ }^{\circledR}$ for desorption allowed the transfer to the GC-MS system of considerably more material than in $1 \mu \mathrm{L}$ or $2 \mu \mathrm{L}$ extracting solution, which can be injected in a GC system. Therefore, the analysis was extended to compounds in low concentration in smoke. Another reason was the intent to protect the injection port and the column of the GC instrument from loading compounds soluble in acetonitrile but not volatile. These compounds may accumulate in the GC injection port and generate decomposition products that will potentially interfere in the chromatographic separation.

With the previously described conditions, a chromatogram of the particulate-phase extract as shown in Figure 2 was obtained for the machine-smoked cigarettes, and as shown in Figure 3 for exhaled smoke. The glycerol peak (at $31.06 \mathrm{~min}$ ) and those of a few other compounds, obtained with the chromatographic column used in this study, have poor shapes. However, the chosen column allows heating up to $320^{\circ} \mathrm{C}$ without considerable bleed and therefore, the detection of high boiling point compounds can be easily 


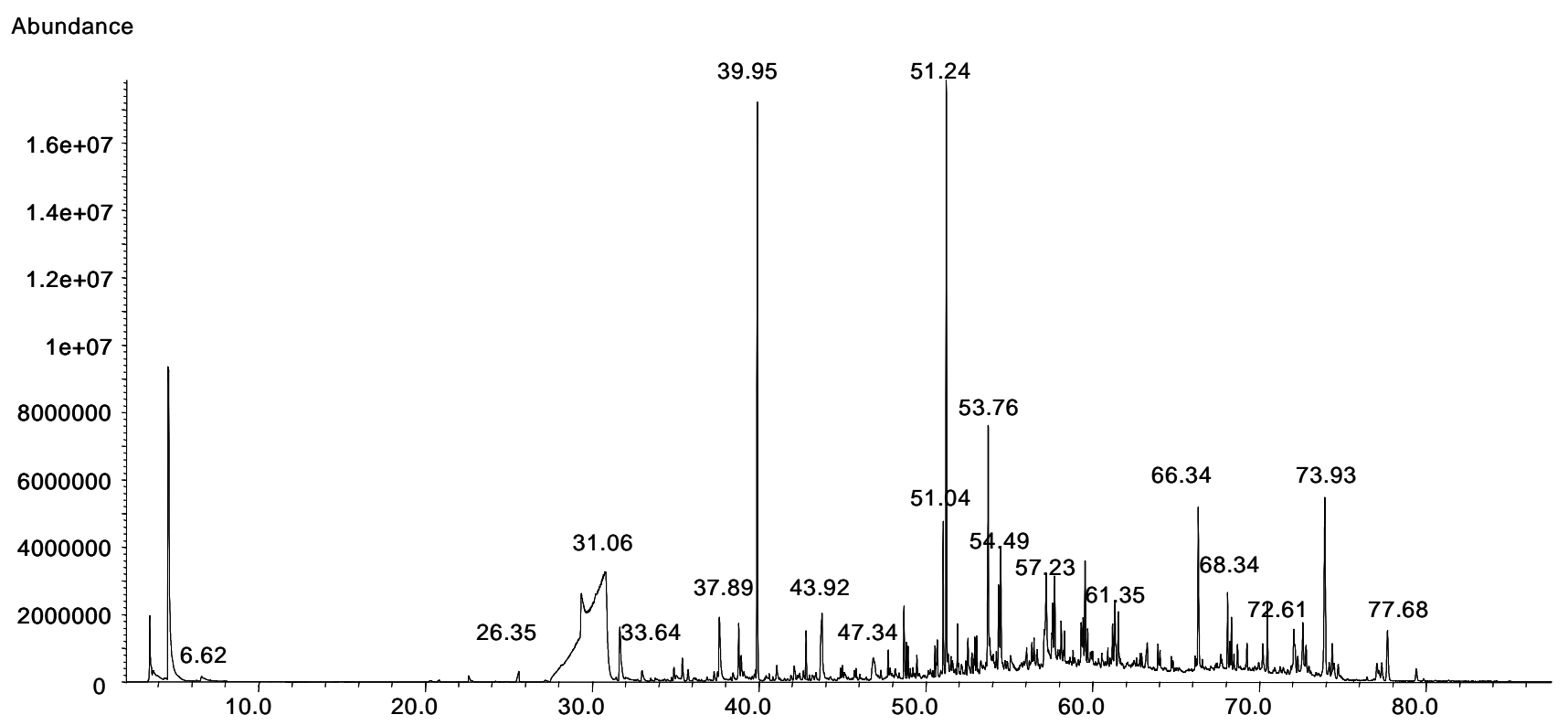

Time-->

Figure 3. Chromatogram of the particulate-phase from exhaled cigarette smoke

achieved. This is not possible with other columns that generate better peak shapes for glycerol (such as Carbowax type columns). The peak areas from the chromatograms were integrated with the aid of the data processing capability of the mass spectral instrumentation. Peaks having an area exceeding a specified threshold level were identified by mass spectral library searches with Wley 275 and NIST'98 libraries. No attempts were made to obtain further verification of peak identity.

\section{Determination of nicotine in the cigarette butts}

One additional analysis performed for this study was that of cigarette butts for nicotine. For the analysis of butt nicotine, the smoked butts were collected and cut into 1$\mathrm{cm}$ lengths. The $1-\mathrm{cm}$ mouth portions of the three cigarettes from each smoker were extracted with $25 \mathrm{~mL}$ methanol containing an internal standard (dodecanol). The level of nicotine was measured by a standard procedure (31) within one day from collection. Other compounds were not measured in the cigarette butts.

\section{RESULTS AND DISCUSSION}

The first step in this study was the identification of the compounds from the smoke condensate by the gas chromatographic separation and mass spectral peak identification. The compounds identified in the particulate-phase smoke from the commercial Lights cigarette evaluated in this study are listed in Table 2 . These compounds were identified initially in the smoke collected from 10 cigarettes on a Cambridge pad from a smoking machine and then in the exhaled-smoke condensate. The number of compounds in smoke is known to be considerably higher than those reported, but the experimental conditions in the study allowed the detection of only a limited number of compounds. Some of the compounds known to be present in cigarette smoke were not detected either because their volatility was different from that of the compounds seen in the chromatogram, or because their level in smoke was too low to assure detection. Some compound identifications by the mass spectra were certain, while other identifications were only tentative. The compounds tentatively identified are denoted in Table 2 by a question mark (?) following the compound name. A few compounds identified only by their mass spectrum were not previously reported to be present in cigarette smoke and are denoted in Table 2 by an asterisk (*). Their identification is also questionable. However, the questionable compounds were not eliminated from Table 2 since they were used to provide information regarding the correlation between the retention of smoke components in a chromatographic column and the retention by the human subjects. All compounds found in the machine-generated smoke were also present in the exhaled smoke, but at different levels.

The comparison between the machine smoke and the exhaled smoke was done by a normalization of the quantity of exhaled smoke condensate to that of FTC smoking conditions. For the cigarettes evaluated in this study the average level of nicotine obtained under machine smoking in FTC conditions was found to be $0.186 \mathrm{mg} /$ (cig butt). The results for butt nicotine measurements from various smokers are given in Table 3. These results were used to generate the normalization factors, which were obtained as the ratio of butt nicotine level from the smoker vs. butt nicotine for the cigarettes machine smoked under FTC conditions.

The nicotine in the cigarette butt $(1 \mathrm{~cm}$ from the mouth end) has a linear dependence on the amount of nicotine collected on the Cambridge pad as previously reported $(32,33)$. This correlation also has been verified for the cigarettes used in this study, for various smoking condi- 
Table 2. Compounds identified in the particulate-phase mainstream smoke of a Lights cigarette listed in the order of their retention times on a DB-5 type chromatographic column ${ }^{\text {a }}$

\begin{tabular}{|c|c|c|c|c|c|}
\hline No. & Compound & MW & CAS Reg. No. & Ret. time & Ave. ret. \% \\
\hline 1 & Acetic acid & 60 & $64-19-7$ & 6.62 & 75.8 \\
\hline 2 & Hexane, 3-methyl- & 100 & $589-34-4$ & 9.80 & 74.8 \\
\hline 3 & Heptane & 100 & $142-82-5$ & 11.08 & 73.2 \\
\hline 4 & Cyclohexane, methyl- & 98 & $108-87-2$ & 12.71 & 74.2 \\
\hline 5 & 1,2-Propanediol (propylene glycol) & 76 & $57-55-6$ & 13.69 & 98.9 \\
\hline 6 & Butanoic acid, 2-methyl- & 102 & $116-53-0$ & 21.70 & 73.9 \\
\hline 7 & 2-Cyclohexen-1-one & 96 & $930-68-7$ & 22.54 & 52.2 \\
\hline 8 & 2,5-Cyclohexadiene-1,4-dione ( $p$-benzoquinone) & 108 & $106-51-4$ & 24.70 & 74.4 \\
\hline 9 & Pentanoic acid, 3-methyl- ( $\beta$-methylvaleric acid) & 116 & $105-43-1$ & 26.35 & 71.7 \\
\hline 10 & Phenol & 94 & $108-95-2$ & 27.41 & 96.5 \\
\hline 11 & Benzene, 1,2,4-trimethyl- (pseudocumene) & 120 & $95-63-6$ & 27.89 & 77.5 \\
\hline 12 & 2-Cyclopenten-1-one, 2-hydroxy-3-methyl- (methylcyclopentenolone) & 112 & $80-71-7$ & 29.14 & 74.9 \\
\hline 13 & Cyclohexene, 1-methyl-4-(1-methylethyl)-, R- (d-limonene) & 136 & $5989-27-5$ & 29.32 & 47.7 \\
\hline 14 & Phenol, 2-methyl- (o-cresol) & 108 & $95-48-7$ & 30.32 & 98.5 \\
\hline 15 & $3(2 H)$-Furanone, 4-hydroxy-2,5-dimethyl (furaneol) & 128 & $3658-77-3$ & 30.49 & 99.3 \\
\hline 16 & Phenol, 4-methyl- ( $p$-cresol) & 109 & $106-44-5$ & 31.03 & 98.7 \\
\hline 17 & 1,2,3-Propanertiol (glycerol) & 92 & $56-81-5$ & 31.06 & 52.4 \\
\hline 18 & Phenol, 2-methoxy- (guaiacol) & 124 & $90-05-1$ & 31.34 & 74.5 \\
\hline 19 & 1,2,3-Propanetriol, monoacetate (monoacetin) & 134 & $26446-35-5$ & 31.81 & 54.3 \\
\hline 20 & 1,2,3-Propanetriol, diacetate (diacetin) & 176 & 25395-31-7 & 31.99 & 88.1 \\
\hline 21 & 3- Pyridinol & 95 & $109-00-2$ & 32.57 & 95.4 \\
\hline 22 & 2,5-Pyrrolidinedione (succinimide) & 99 & $123-56-8$ & 33.22 & 81.6 \\
\hline 23 & 4H-Pyran-4-one, 2,3-dihydro-3,5-dihydoxy-6-methyl- & 144 & 28564-83-2 & 33.64 & 91.0 \\
\hline 24 & 2,4-Imidazolidinedione, 5-ethyl- (5-ethylhydantoin) & 128 & $15414-82-1$ & 33.82 & 74.7 \\
\hline 25 & Phenol, 4-ethyl- & 122 & 123-07-9 & 34.23 & 92.1 \\
\hline 26 & 2H-Pyran-2-one, 5,6-dihydro-6-propyl- & 140 & $16400-69-4$ & 34.36 & 86.1 \\
\hline 27 & Benzoic acid & 122 & $65-85-0$ & 34.54 & 98.7 \\
\hline 28 & 4H-Pyran-4-one, 5-hydroxy-2-methyl- & 126 & $644-46-2$ & 34.97 & 99.4 \\
\hline 29 & 2(3H)-Furanone, dihydro-5-propyl- ( $($-heptalactone) & 128 & $105-21-5$ & 35.14 & 75.5 \\
\hline 30 & 1,2-Benzenediol (catechol) & 110 & $120-80-9$ & 35.30 & 93.2 \\
\hline 31 & Benzofuran, 2,3-dihydro- (coumaran) & 120 & $496-16-2$ & 35.92 & 90.1 \\
\hline 32 & 2-Furancarboxaldehyde, 5-hydroxymethyl- & 126 & $67-47-0$ & 36.10 & 53.1 \\
\hline 33 & Propanetriol diacetate isomer? & 176 & $?$ & 36.28 & 89.0 \\
\hline 34 & Phenol, 3-ethyl-5-methyl- (5-ethyl- $m$-cresol) & 136 & $698-71-5$ & 36.45 & 99.0 \\
\hline 35 & Benzeneacetic acid (phenylacetic acid) & 136 & $103-82-2$ & 37.09 & 99.5 \\
\hline 36 & 1,2-Benzenediol, 4-methyl- (4-methylcatechol) & 124 & $452-86-8$ & 37.41 & 98.6 \\
\hline 37 & 1,4-Benzenediol (hydroquinone) & 110 & $123-31-9$ & 37.89 & 82.9 \\
\hline 38 & $1 H$-Indole & 117 & $120-72-9$ & 38.36 & 70.4 \\
\hline 39 & Ethanone, 1-(2-hydroxy-5-methylphenyl)- & 150 & $1450-72-2$ & 38.72 & 98.5 \\
\hline 40 & Pentanedioic acid, 3-methyl- & 146 & $626-51-7$ & 38.89 & 99.4 \\
\hline 41 & 1,2,3-Propanetriol, triacetate (triacetin) & 218 & $102-76-1$ & 39.06 & 98.8 \\
\hline 42 & Pyrrolidine, diethyl- & 125 & 71607-78-8 & 39.23 & 98.5 \\
\hline 43 & Phenol, 2,6-dimethoxy- (syringol) & 154 & $91-10-1$ & 39.71 & 80.4 \\
\hline 44 & Pyridine, 3-(1-methyl-2-pyrrolidinyl)-, (S)- (nicotine) & 162 & $54-11-5$ & 39.95 & 84.6 \\
\hline $45^{\star}$ & 1,2-Benzenediol monoacetate & 152 & $102-29-4$ & 40.34 & 84.4 \\
\hline 46 & 1,2-Benzenediol, 4-ethyl- & 138 & $1124-39-6$ & 40.54 & 89.0 \\
\hline 47 & 1,4-Benzenediol, 2,3-dimethyl- & 138 & $608-43-5$ & 40.62 & 82.3 \\
\hline 48 & $1 \mathrm{H}$-Indole, 2-methyl- & 131 & $95-20-5$ & 40.98 & 74.5 \\
\hline 49 & Benzaldehyde, 4-hydroxy-3-methoxy- (vanillin) & 152 & $121-33-5$ & 41.21 & 89.6 \\
\hline 50 & Anhydrosugar & $162 ?$ & & 41.27 & 71.1 \\
\hline 51 & Benzeneethanol, 3-hydroxy- (3-hydroxyphenethyl alcohol) & 138 & $13398-94-2$ & 41.99 & 98.7 \\
\hline 52 & Pyridine, 3-(3,4-dihydro-2H-pyrrol-5-yl)- (myosmine) & 146 & $532-12-7$ & 42.13 & 89.1 \\
\hline 53 & Benzene, 4-ethenyl-1,2-dimethoxy- & 164 & $6380-23-0$ & 42.44 & 81.7 \\
\hline 54 & Cyclohexanone, 2-methyl-5-(1-methylethenyl)- (dihydrocarvone) & 152 & $7764-50-3$ & 42.81 & 81.9 \\
\hline 55 & Unknown & $160 ?$ & & 43.04 & 85.4 \\
\hline 56 & Pyridine, 3-(1-methyl-1H-pyrrol-2-yl)- (nicotyrine) & 158 & $487-19-4$ & 43.38 & 77.9 \\
\hline 57 & $\beta$-D-Glucopyranose, 1,6-anhydro- (levoglucosan) & 162 & $498-07-7$ & 43.92 & 71.7 \\
\hline 58 & Unknown & $182 ?$ & & 44.13 & 98.8 \\
\hline $59^{*}$ & Pyrimidine, 5-hydroxy-4-phenyl- & 172 & $88070-43-3$ & 44.37 & 98.8 \\
\hline 60 & 1-Naphthalenol (1-naphthol) & 144 & $90-15-3$ & 44.56 & 98.7 \\
\hline 61 & 2,3'-Bipyridine (2,3'-dipyridyl) & 156 & $581-50-0$ & 45.00 & 74.7 \\
\hline $62^{*}$ & Benzaldehyde, 2,5-dimethoxy-4-methyl- & 180 & $4925-88-6$ & 45.18 & 79.7 \\
\hline 63 & Mixture & & & 45.75 & 68.7 \\
\hline 64 & 1,2-Benzenedicarboxylic acid, diethyl ester (diethyl phthalate) & 222 & $84-66-2$ & 45.83 & 69.0 \\
\hline
\end{tabular}




\begin{tabular}{|c|c|c|c|c|c|}
\hline No. & Compound & MW & CAS Reg. No. & Ret. time & Ave. ret. \% \\
\hline 65 & $\begin{array}{l}\text { 2-Buten-1-one, (1-(3-hydroxy-2,6,6-trimethyl-1-cyclohexen-1-yl)- (3- } \\
\text { hydroxy- } \beta \text {-damascone) }\end{array}$ & 208 & $102488-09-5$ & 46.53 & 84.0 \\
\hline $66^{*}$ & $1 H$-midazole, 1,4-dimethyl-5-phenyl- & 172 & $1131-16-4$ & 46.70 & 98.7 \\
\hline 67 & Mixture & & & 46.99 & 75.7 \\
\hline 68 & $\alpha$-Ionol, 3-oxo- & 208 & N/A & 47.15 & 99.8 \\
\hline 69 & 2-Cyclohexen-1-one,4-(3-hydroxy-1-butenyl)-3,5,5-trimethyl- $\left[\mathrm{R}-\left[\mathrm{R}^{*}, \mathrm{R}^{*}-(\mathrm{E})\right]\right]$ & 208 & $52210-15-8$ & 47.34 & 88.3 \\
\hline 70 & Dodecanol & 186 & $112-53-8$ & 48.05 & 39.3 \\
\hline 71 & Ethanone, 1,1',1"-(1,3,5-benzenetriyl)tris- + 2-phenylphenol & $204+170$ & $779-90-8$ & 48.16 & 67.9 \\
\hline 72 & Phenol, 2,6-dimethoxy-4-(2-propenyl)- & 194 & $6627-88-9$ & 48.44 & 98.8 \\
\hline 73 & $\begin{array}{l}\text { 2-Cyclohexen-1-one,4-(3-hydroxybutyl)-3,5,5-trimethyl- [(9R)-9-hydroxy-4- } \\
\text { megastigmen-3-one] }\end{array}$ & 210 & $36151-02-7$ & 48.75 & 9.1 \\
\hline $74^{*}$ & Cycloundecane, 1,1,2-trimethyl- & 196 & $62376-15-2$ & 48.84 & 61.7 \\
\hline 75 & 2-Pyrrolidinone, 1-methyl-5-(3-pyridinyl)- (cotinine) & 176 & $486-56-6$ & 48.99 & 71.1 \\
\hline $76^{*}$ & $1 H$-Indole, 1,3-dibutyl- & 186 & $55191-12-3$ & 49.12 & 18.7 \\
\hline $77^{*}$ & 1,1'-Biphenyl-2,3-diol & 186 & $1133-63-7$ & 49.27 & 82.9 \\
\hline 78 & Tetradecanoic acid (myristic acid) & 228 & $544-63-8$ & 49.49 & 65.8 \\
\hline 79 & Cyclohexane, 1,5-diisopropyl-2,3-dimethyl- & 196 & $\mathrm{~N} / \mathrm{A}$ & 50.23 & 72.1 \\
\hline 80 & 1,4-Naphthalenedione, 2,3,6-trimethyl- & 200 & $20490-42-0$ & 50.35 & 43.6 \\
\hline $81^{*}$ & Phenol, 3-methoxy-, acetate & 166 & $5451-83-2$ & 50.56 & 73.7 \\
\hline 82 & 1-Pyrrolidinecarboxaldehyde, 2-(3-pyridinyl)-, (S)- (N-formylnornicotine) & 176 & $3000-81-5$ & 50.73 & 68.5 \\
\hline $83^{*}$ & Propanoic acid, 3-(ethoxycarbonyl)-3-(1-cyclohexenyl)- ? & 226 & $82546-67-6$ & 51.05 & 73.7 \\
\hline 84 & 1-Hexadecene, 3-methylene-7,11,15-trimethyl- (neophytadiene) & 278 & $504-96-1$ & 51.25 & 45.7 \\
\hline 85 & 2-Pentadecanone, 6,10,14-trimethyl- (hexahydrofarnesylacetone) & 268 & $502-69-2$ & 51.36 & 72.9 \\
\hline 86 & $\begin{array}{l}\text { 2-Cyclohexen-1-one, 4-(1,3-butadienyl)-3,5,5-trimethyl- (E)-, } \\
\text { (megastigmatrienone) }\end{array}$ & 190 & $38818-55-2$ & 51.52 & 1.2 \\
\hline 87 & $\begin{array}{l}\text { 2,3-Naphthalenediol, 1,2,3,4,5,6,7,8-octahydro-1-methyl-7-(1- } \\
\text { methylethenyl)- (rishitin) }\end{array}$ & 222 & $18178-54-6$ & 51.62 & 99.1 \\
\hline 88 & 1,2-Benzenedicarboxylic acid, butyl-, 2-ethylhexyl ester & 334 & $85-69-8$ & 51.91 & 1.0 \\
\hline 89 & Phytol type & 296 & $150-86-7 ?$ & 52.15 & 63.1 \\
\hline 90 & $1 \mathrm{H}$-Purine-2,6-dione, 3,7-dihydro-3,7-dimethyl- (theobromine) & 180 & $83-67-0$ & 52.56 & 67.0 \\
\hline 91 & Hexadecanone & 240 & $18787-63-8$ & 52.77 & 63.7 \\
\hline 92 & 2,6,10-Dodecatrien-1-ol, 3,7,11-trimethyl- (farnesol isomer A) & 222 & N/A & 52.96 & 84.3 \\
\hline 93 & Hexadecanoic acid, methyl ester & 270 & $112-39-0$ & 53.03 & 1.4 \\
\hline 94 & 1,4-Pentanediol, 3-[1S,2S]-2-(2-hydroxyethyl)-1,3,3-trimethyl-cyclohexyl- & 272 & N/A & 53.32 & 43.0 \\
\hline $95^{\star}$ & Benzoin acetate & 254 & $574-06-1$ & 53.45 & 99.6 \\
\hline 96 & $n$-Hexadecanoic acid (palmitic acid) & 256 & $57-10-3$ & 53.76 & 60.5 \\
\hline 97 & Pyrrolo[1,2a]pyrazine-1,4-dione, hexahydro-3-(2-methylpropyl)- & 210 & $5654-86-4$ & 53.87 & 42.2 \\
\hline 98 & Benzofuran-2,3-dione, 4,7-dimethyl-2,3-dihydro- & 176 & $31297-30-0$ & 54.09 & 23.6 \\
\hline $99^{*}$ & Octadecadiynoic acid, methyl ester & 290 & $56847-03-1$ & 54.24 & 82.0 \\
\hline 100 & Hexadecanoic acid, ethyl ester (ethyl palmitate) & 284 & $628-97-7$ & 54.37 & 0.6 \\
\hline 101 & 2H-1-Benzopyran-2-one, 7-hydroxy-6-methoxy- (scopoletin) & 192 & $92-61-5$ & 54.42 & 9.1 \\
\hline 102 & Eicosane & 282 & $112-95-8$ & 54.50 & 19.1 \\
\hline 103 & $9 H$-Pyrido[3,4-b]indole, 1-methyl- (harman) & 182 & $486-84-0$ & 54.73 & 60.1 \\
\hline 104 & $9 H$-Pyrido[3,4-b]indole (norharman) & 168 & 244-63-3 & 55.14 & 23.4 \\
\hline 105 & Dioxobenzofuran, 2,3-dihydro-4,6,7-trimethyl- & 190 & 31297-33-3 & 55.21 & 99.0 \\
\hline 106 & 2,6,10-Dodecatrien-1-ol, 3,7,11-trimethyl- (farnesol) & 222 & $4602-84-0$ & 55.58 & 86.0 \\
\hline 107 & $\begin{array}{l}\text { Propanedioic acid, (phenylmethyl)-, diethyl ester? } \\
\text { (diethyl benzylmalonate) }\end{array}$ & $250 ?$ & $607-81-8$ & 55.74 & 82.0 \\
\hline 108 & $\begin{array}{l}\text { 4,8,13-Cyclotetradecatriene-1,3-diol, 1,5,9-trimethyl-12-(1-methylethyl)- } \\
\text { (4,8,13-duvatriene-1,3-diol, isomer 1) }\end{array}$ & 306 & 7220-78-2 & 56.06 & 76.4 \\
\hline $109^{*}$ & 4H-Pyrido[1,2-a]pyrimidine-3-acetic acid, 9-hydroxy-4-oxo-, ethyl ester & 248 & $50609-61-5$ & 56.21 & 61.9 \\
\hline 110 & $\begin{array}{l}\text { 4,8,13-Cyclotetradecatriene-1,3-diol, 1,5,9-trimethyl-12-(1-methylethyl)- } \\
\text { (4,8,13-duvatriene-1,3-diol, isomer 2) }\end{array}$ & 306 & $57605-80-8$ & 56.37 & 83.0 \\
\hline 111 & 9,12,15-Octadecatrienoic acid, methyl ester (methyl linolenate) & 292 & $301-00-8$ & 56.51 & 21.1 \\
\hline 112 & 2-Hexadecen-1-ol, 3,7,11,15-tetramethyl- (phytol) & 296 & $150-86-7$ & 56.70 & 68.5 \\
\hline 113 & 9,12-Octadecadienoic acid (linoleic acid) & 280 & $60-33-3$ & 57.06 & 74.8 \\
\hline 114 & 9-Octadecenoic acid (oleic acid) & 282 & $112-80-1$ & 57.17 & 77.0 \\
\hline 115 & $9,12,15$-Octadecatrienoic acid $(Z, Z, Z)(\alpha$-linolenic acid) & 278 & $463-40-1$ & 57.23 & 30.0 \\
\hline 116 & Octadecanoic acid (stearic acid) & 284 & $57-11-4$ & 57.56 & 4.1 \\
\hline 117 & 1-Docosene & 308 & $1599-67-3$ & 57.61 & 1.7 \\
\hline 118 & Ethyl oleate & 310 & $111-62-6$ & 57.70 & 1.6 \\
\hline 119 & Octadecanoic acid, ethyl ester (ethyl stearate) & 312 & $111-61-5$ & 58.12 & 1.0 \\
\hline 120 & Docosane & 310 & $629-97-0$ & 58.32 & 3.3 \\
\hline 121 & $\begin{array}{l}\text { 2,7,11-Cyclotetradecatrien-1-ol, 4-(1-methylethyl)-1,7,11-trimethyl- } \\
\text { (isocembrol) }\end{array}$ & 290 & $25269-17-4$ & 58.83 & 0.8 \\
\hline
\end{tabular}




\begin{tabular}{|c|c|c|c|c|c|}
\hline No. & Compound & MW & CAS Reg. No. & Ret. time & Ave. ret. \% \\
\hline 122 & $\begin{array}{l}\text { Hexadecanoic acid, 2-hydroxy-1-(hydroxy-methyl)ethyl ester (2- } \\
\text { monopalmitin) }\end{array}$ & 330 & $23470-00-0$ & 59.31 & 13.3 \\
\hline 123 & Phytosterol-type & & $\mathrm{N} / \mathrm{A}$ & 59.44 & 3.9 \\
\hline 124 & 1,1',3'-Terphenyl-2'-ol & 246 & $2432-11-3$ & 59.57 & 4.4 \\
\hline 125 & Farnesol type & 288 & $\mathrm{~N} / \mathrm{A}$ & 59.71 & 5.4 \\
\hline 126 & Tricosane & 324 & $638-67-5$ & 60.01 & 1.1 \\
\hline 127 & 2-Eicosanol & 298 & $4340-76-5$ & 60.92 & 23.0 \\
\hline $128^{*}$ & 4,8,12,16-Tetramethylheptadecan-4-olide? & $324 ?$ & $96168-15-9$ & 61.06 & 1.5 \\
\hline 129 & $2,6,10,14,18$-Eicosapentaene, $2,6,10,14,18$ - pentamethyl-? & 342 & 75581-03-2 & 61.21 & 5.1 \\
\hline 130 & $2,6,10,14,18$-Eicosapentaene, $2,6,10,14,18$ - pentamethyl- isomer & 342 & $\mathrm{~N} / \mathrm{A}$ & 61.35 & 18.1 \\
\hline $131^{*}$ & 1,3-Isobenzofurandione, 5-(1,1-dimethyl-1-heptyl)- ? & $274 ?$ & $\mathrm{~N} / \mathrm{A}$ & 61.55 & 36.5 \\
\hline $132^{*}$ & 2,2':6',2"-Terpyridine & 233 & $1148-79-4$ & 62.65 & 10.5 \\
\hline 133 & $2,6,10,14,18$-Eicosapentaene, $2,6,10,14,18$ - pentamethyl- isomer & 342 & $\mathrm{~N} / \mathrm{A}$ & 62.85 & 1.4 \\
\hline 134 & Pentacosane & 352 & $629-99-2$ & 63.28 & 3.1 \\
\hline 135 & 1,2-Benzenedicarboxylic acid, diisooctyl ester & 390 & $27554-26-3$ & 63.93 & 1.4 \\
\hline 136 & Heptacosene? & 378 & $\mathrm{~N} / \mathrm{A}$ & 64.05 & 1.0 \\
\hline 137 & Docosanoic acid, ethyl ester (ethyl behenate) & 368 & $5908-87-2$ & 64.74 & 27.4 \\
\hline 138 & Sterol type & 400 & & 6615 & 28.3 \\
\hline 139 & Nonacosane & 408 & $630-03-5$ & 66.34 & 2.4 \\
\hline 140 & 2,6,10,14,18,22-Tetracosahexaene, 2,6,10,15,19,23-hexamethyl- & 410 & $111-02-4$ & 68.09 & 0.6 \\
\hline 141 & $2,6,10,14,18$-Eicosapentaene, pentamethyl-2,6,10,14,18- isomer & 342 & $\mathrm{~N} / \mathrm{A}$ & 68.24 & 0.9 \\
\hline 142 & Farnesol type & 424 & $\mathrm{~N} / \mathrm{A}$ & 68.34 & 6.0 \\
\hline 143 & $2,6,10,14,18,22$-Tetracosahexaene, 2,6,10,15,19,23-hexamethyl- isomer & 410 & $111-02-4$ & 68.49 & 36.1 \\
\hline 144 & Hentriacontane & 436 & $630-04-6$ & 68.70 & 4.5 \\
\hline 145 & Hentriacontane isomer & 436 & $\mathrm{~N} / \mathrm{A}$ & 69.27 & 1.3 \\
\hline 146 & Cholesta-3,5-diene (cholesterylene) & 368 & $747-90-0$ & 70.22 & 1.2 \\
\hline 147 & Dotriacontane & 450 & $544-85-4$ & 70.49 & 0.9 \\
\hline 148 & Cholest-4-en-3-ol, 4-methyl-, $(3 \alpha)$ & 400 & $96443-01-5$ & 72.14 & 1.4 \\
\hline 149 & $\beta$-Tocopherol & 416 & $148-03-8$ & 72.30 & 14.3 \\
\hline 150 & Stigmasta-3,5,22-triene & 394 & $81531-12-6$ & 72.61 & 11.6 \\
\hline 151 & Dotriacontane isomer & 450 & $N / A$ & 72.80 & 1.6 \\
\hline 152 & $\alpha$-Tocopherol & 430 & $59-02-9$ & 73.93 & 20.3 \\
\hline 153 & Sterol type & 394 & $\mathrm{~N} / \mathrm{A}$ & 74.19 & 15.2 \\
\hline 154 & Tritriacontane & 464 & $630-05-7$ & 74.37 & 1.4 \\
\hline 155 & Cholest-5-en-3-ol (3ß)- ? (cholesterol) & 386 & $57-88-5$ & 74.48 & 13.3 \\
\hline 156 & Sterol type & 400 & N/A & 74.73 & 1.2 \\
\hline 157 & Ergost-5-en-3-ol, (3ß,24R)- (campesterol) & 400 & $474-62-4$ & 77.05 & 1.4 \\
\hline 158 & $2,6,10,14,18,22$-Tetracosahexaene, $2,6,10,15,19,23$-hexamethyl- isomer & 410 & $\mathrm{~N} / \mathrm{A}$ & 77.34 & 1.1 \\
\hline 159 & Stigmasta-5,22-dien-3-ol (3ß,22R)- (stigmasterol) & 412 & $83-48-7$ & 77.68 & 1.2 \\
\hline 160 & Stigmasta-5-en-3-ol (3ß)- (sitosterol) & 414 & $83-47-6$ & 79.41 & 1.0 \\
\hline
\end{tabular}

${ }^{a}$ The compounds tentatively identified are denoted by a question mark (?) following the compound name. A few compounds identified only by their mass spectrum were not previously reported to be present in cigarette smoke and are denoted by an asterisk $\left({ }^{*}\right)$.

Table 3. Nicotine levels in the human-smoked cigarette butts and the corresponding correction factor used for the normalization to the condensate obtained with FTC conditions

\begin{tabular}{l|c|c}
\hline Smoker & Butt nicotine in $\mathrm{mg} / \mathrm{cig}$ & Correction factor \\
\hline No. 1 & 0.179 & 1.0307 \\
No. 2 & 0.177 & 1.0423 \\
No. 3 & 0.318 & 0.5811 \\
No. 4 & 0.202 & 0.9149 \\
No. 5 & 0.242 & 0.7633 \\
No. 6 & 0.207 & 0.8928 \\
No. 7 & 0.180 & 1.0250 \\
No. 8 & 0.241 & 0.7674 \\
\hline
\end{tabular}

tions (FTC as well as with increased puff volume and frequency). The curve showing the dependence of mainstream nicotine level as collected on a Cambridge pad vs. butt nicotine generated for the studied cigarette is shown in
Figure 4 . The $R^{2}$ value for the linear dependence is 0.946 indicating a strong correlation. Also, the TPM on the pad had a linear correlation with the butt nicotine. The linear curve showing this dependence is given in Figure 5, the $R^{2}$ value being 0.950 .

In the present study, all compounds in the smoke condensate were assumed to have a linear dependence on the level of nicotine in the cigarette butt (and consequently to the level of TPM on the pad). This linearity assumption is only an approximation, and its validity was evaluated for a number of compounds by machine smoking the cigarettes in three different regimes including FTC and two specific intensive smoking conditions. These intensive conditions used $2 \mathrm{sec}$ puff duration, $45-\mathrm{mL}$ puff volume, and $30-\mathrm{sec}$ puff interval (indicated as 45/30), and 2-sec puff duration, 60-mL puff volume, and 30-sec puff interval (indicated as 60/30). The smoking has been performed in duplicate and the TPM average values for the three smoking regimes were $12.4 \mathrm{mg}$ (FTC), $26.9 \mathrm{mg}$ (45/30) and $36.8 \mathrm{mg}$ (60/30). 


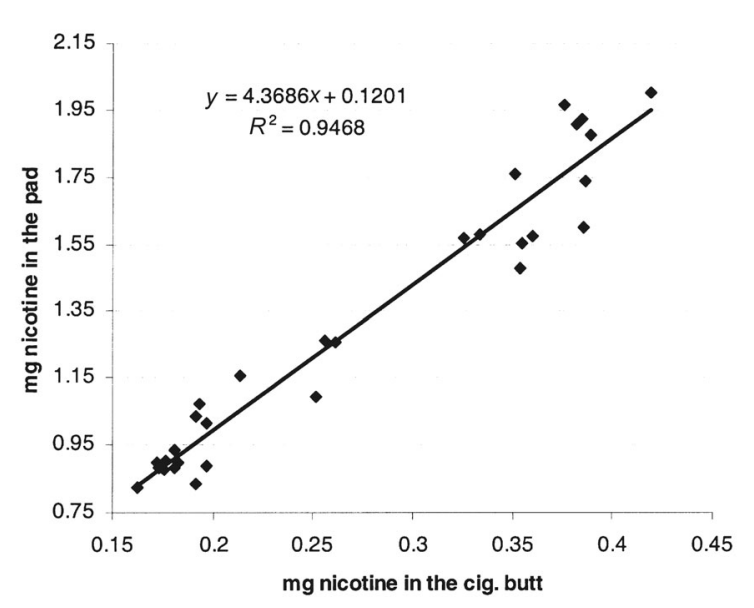

Figure 4. Nicotine levels on the Cambridge pad as a function of the nicotine level in the cigarette butt for the Lights commercial cigarette evaluated in this study

The ratio of TPM values for 45/30 vs. FTC was found to be 2.17 and that for $60 / 30$ vs. FTC was 2.97 . The ratios of the peak areas of corresponding compounds in the chromatograms obtained by the two intensive smoking regimes vs. FTC smoking were further calculated and are shown in Figure 6 (for selected compounds). As seen in Figure 6 the ratios for the two intensive smoking regimes vs. FTC smoking are very close to the corresponding TPM ratios. Within the expected variability, this indicates that the majority of the evaluated compounds increase in a linear manner with the TPM. Similar results regarding the linear dependence (with a positive slope) of the level of various compounds on pad nicotine (and on 'tar' levels where 'tar' $=$ TPM - nicotine - water) have been found in the 1999 Massachusetts Benchmark Study (34). The results in the Massachusetts Benchmark Study were generated from a variety of cigarette brands smoked under Massachusetts

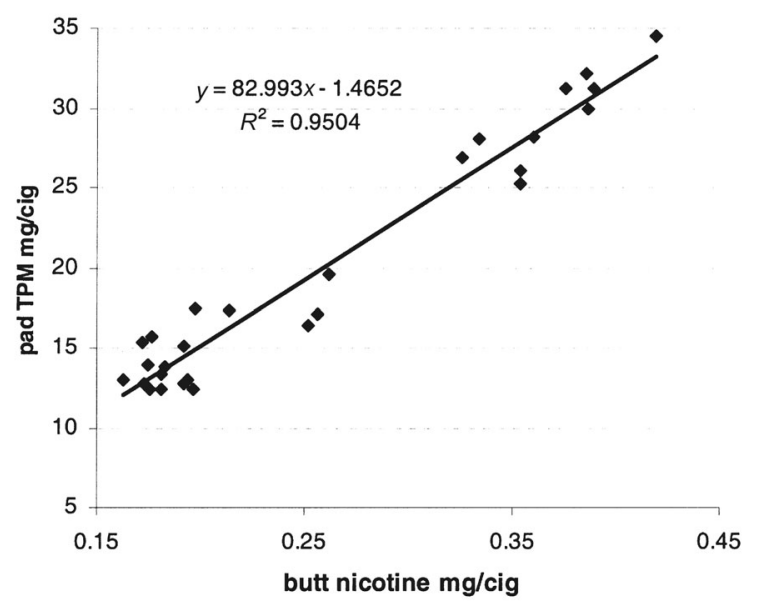

Figure 5. Cambridge pad total particulate matter (TPM) as a function of the nicotine level in the cigarette butt for the Lights commercial cigarette evaluated in this study

recommended conditions, and not from the same cigarette smoked in different smoking regimes. Also, not all compounds from the particulate-phase showed linear dependence. Nevertheless, the results from the Massachusetts Benchmark Study provide additional confirmation for considering as a first approximation that the variation in the levels of many compounds from smoke condensate is proportional to that of nicotine yields and TPM levels.

One other question regarding exhaled smoke composition is related to the variation of retention as a function of human smoking characteristics, such as inhalation volume and breath-hold duration. The influence of these factors has been only recently reported for nicotine and solanesol (7), although a few older studies not published in the peerreviewed literature existed (15). From the results previously reported (7), the ratio (\%) for the retention of nicotine vs. solanesol as a function of inhalation volume does not vary

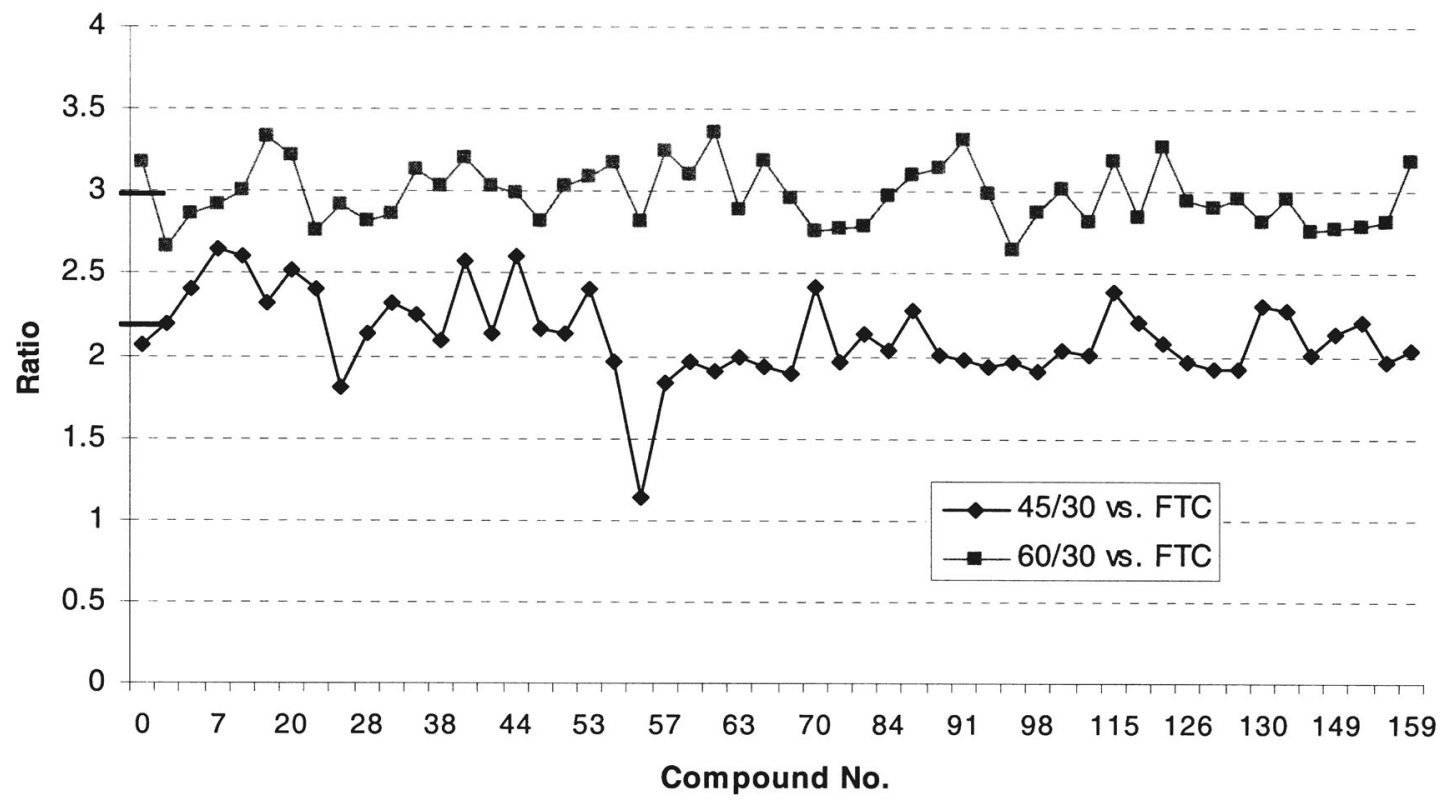

Figure 6. The ratios of the peak areas of corresponding compounds in the chromatograms obtained using $45 / 30 \mathrm{vs.} \mathrm{FTC} \mathrm{and} 60 / 30$ vs. FTC smoking regimes. The ratios for the TPM values of $45 / 30$ vs. FTC and of $60 / 30$ vs. FTC smoking regimes are indicated as bars at the beginning of each plot. 


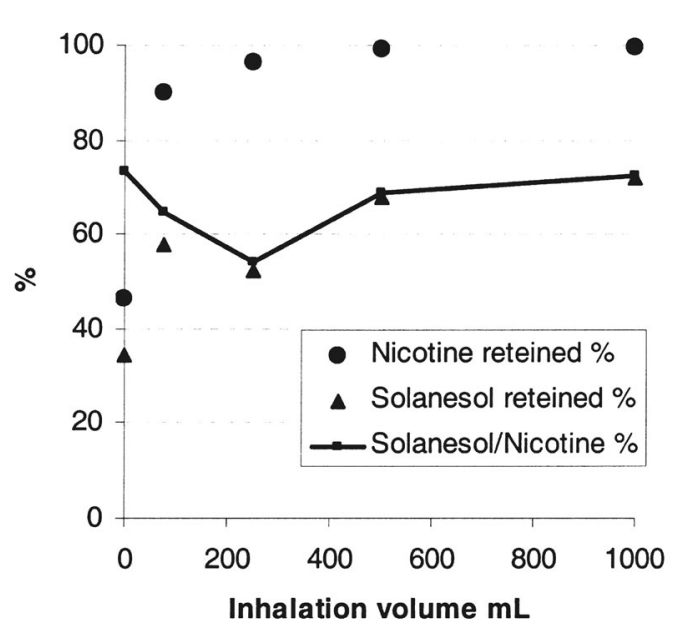

Figure 7. Results reported in the literature (7) regarding the retention of nicotine and solanesol as a function of inhalation volume and the ratio (\%) of the two retention values significantly beyond a certain inhalation volume. This is shown in Figure 7 based on literature data. Breath-hold duration seems to influence the retention of different compounds more, as shown for nicotine and solanesol (7). In the present study, the inhalation volume and breath-hold duration were not monitored. The smoking was done with as little as possible change from typical for each smoker, and the variability in the results obtained in the present study may reflect in part this type of variation.

The comparison of the chemical composition of the particulate-phase of exhaled mainstream smoke with that of smoke collected with a Borgwaldt RM20 CSR smoking machine working under FTC conditions is shown in Figures $8 \mathrm{a}$ and $8 \mathrm{~b}$. The results are presented as retention percentage. The retention percentage was calculated from peak area ratios in exhaled smoke (corrected with the factor shown in Table 3) vs. machine smoke for each compound analyzed, using the expression:

Retention $\%=(1-$ Peak area exhaled/Peak area machine smoked) $\times 100$

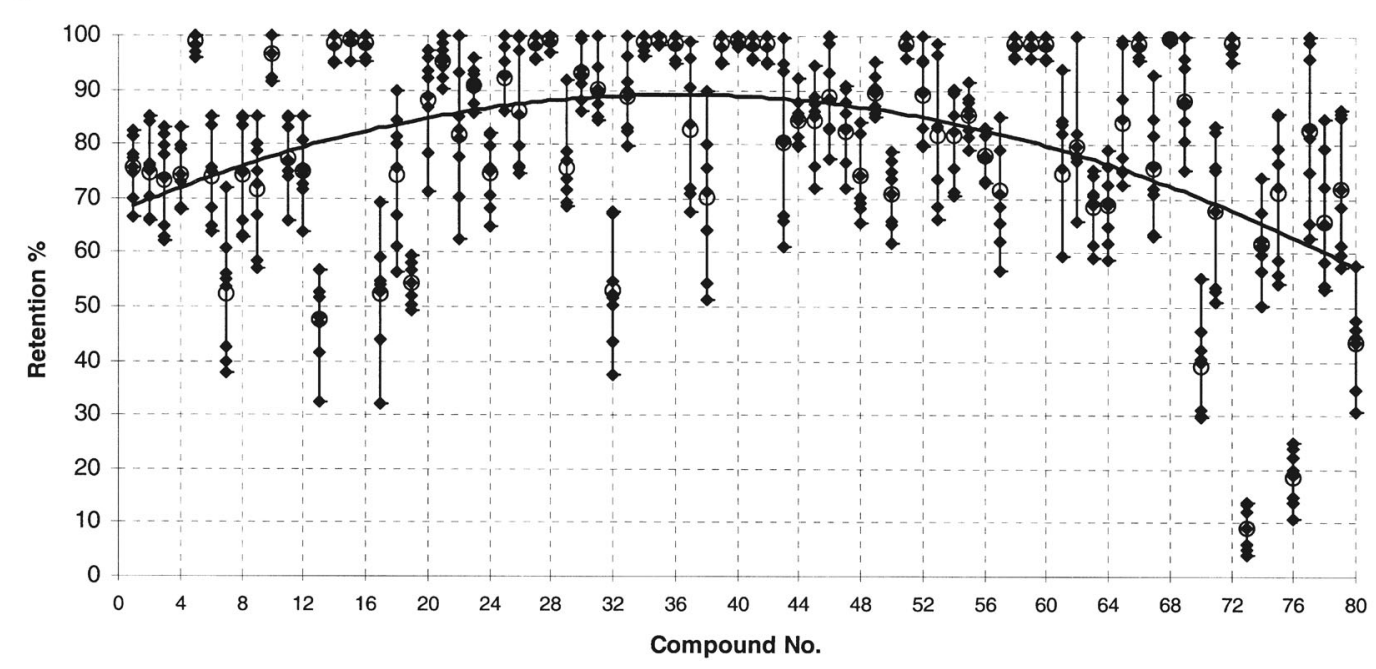

Figure 8a. Retention of mainstream smoke components by eight human subjects as obtained by comparing exhaled smoke composition (normalized to butt nicotine for FTC smoking) with that of machine-generated smoke (first 80 compounds from Table 2.) The eight points for each compound represent different smokers. The trendline is generated for the average points (shown as a circle)

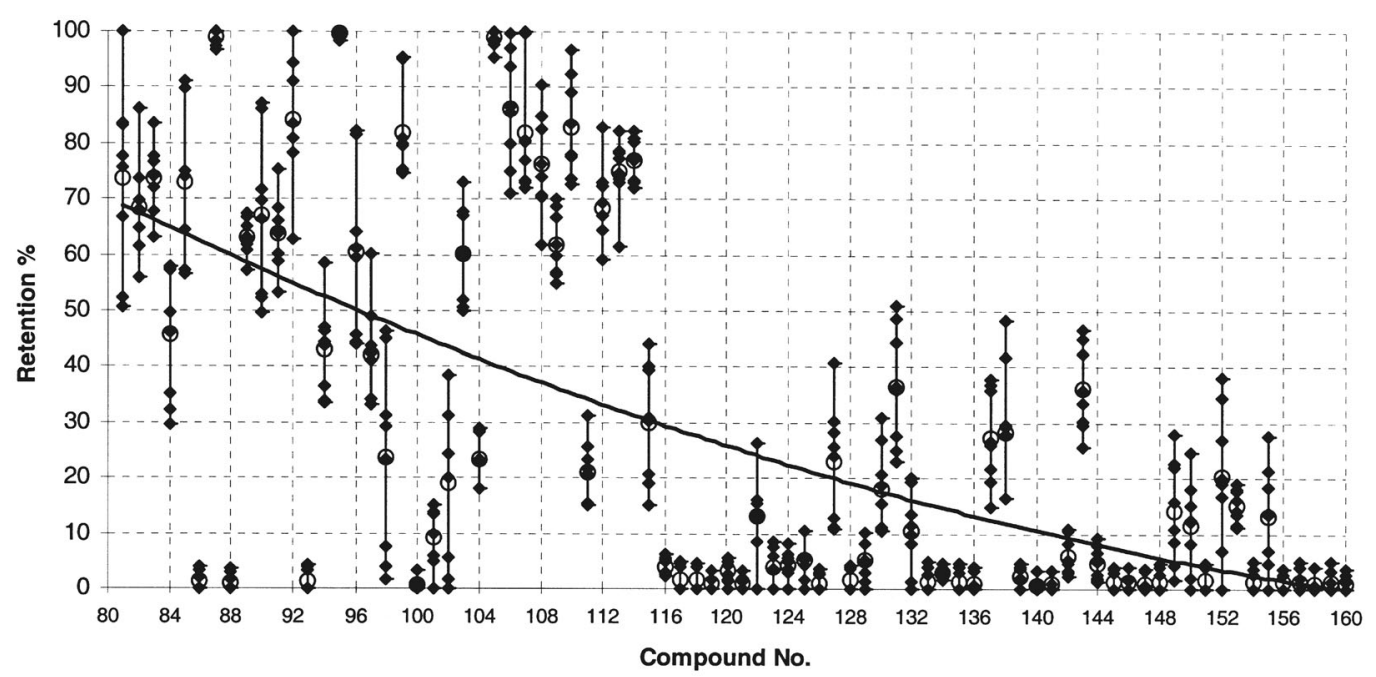

Figure $8 \mathrm{~b}$. Retention of mainstream smoke components by eight human subjects as obtained by comparing exhaled smoke composition (normalized to butt nicotine for FTC smoking) with that of machine-generated smoke (last 80 compounds from Table 2.) The eight points for each compound represent different smokers. The trendline is generated for the average points (shown as a circle) 


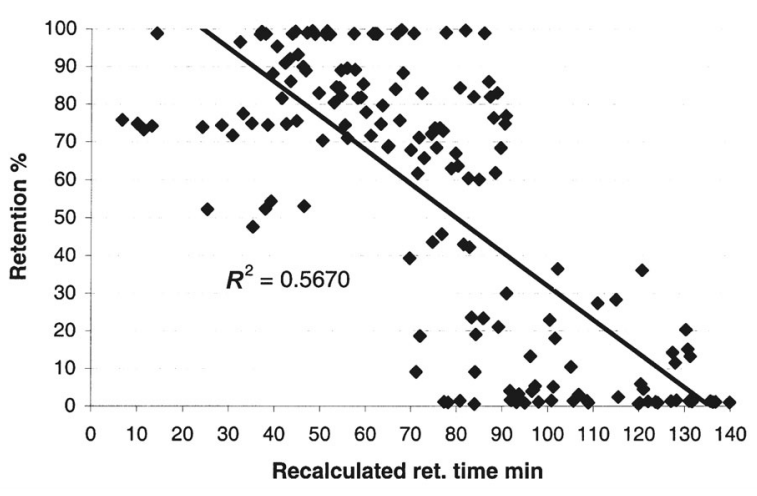

Figure 9. The dependence between the retention of smoke components by the human subjects and the recalculated chromatographic retention time (on a DB5 column) of several compounds from smoke

The compounds are arranged in the order of their elution from the chromatographic column, the numbers on the $x$ axis in Figures $8 \mathrm{a}$ and $8 \mathrm{~b}$ correspond to the compound number given in Table 2. Eight values, corresponding to each smoker, were generated for each compound, and the graphs show also the average values (as points). The averages of the retentions for each compound are also given in Table 2. For some compounds the differences between the average value and the extremes were less than $5 \%$. However, the typical variability in the chromatographic analysis in this study is around $5 \%$ as found by performing repeated chromatographic runs from the same sample (data not presented).

Figures $8 \mathrm{a}$ and $8 \mathrm{~b}$ show a very interesting pattern regarding the retention of the compounds from cigarette smoke. As seen in these figures, about one third of the compounds were retained by more than $66 \%$. These were in general lower molecular weight compounds, which were eluted early from the chromatographic column. The trendline (for the average values) shows a slightly lower retention $\%$ for the earlier compounds with a maximum around the $35^{\text {th }}$ compound. It is not clear if this is a real trend, or an artifact. If real, this trend may show that compounds with a higher propensity to stay in the vapor phase are not as well retained as other small molecules of more polar compounds with high water solubility. Although evaluated on a limited number of subjects, the results for individual compounds did not show a very large scatter, indicating that the retention process is not very different among the evaluated subjects.

Another third of the compounds were retained between $33 \%$ and $66 \%$. These are compounds eluting in the mid range of the retention times for the chromatographic separation. They have lower volatility than the first group. The last third of the compounds are even less retained from smoke. They were heavier compounds, with higher boiling points, which were eluted late from the chromatographic column. This group includes mainly long-chain hydrocarbons (saturated or squalene type) and phytosterol-type compounds. Polycyclic aromatic hydrocarbons were at too low levels to be measured in this study.

The comparison of the retentions determined in this study with the data available in the literature shows very good agreement for most compounds. Nicotine shows in this study retention between $80 \%$ and $92 \%$ ( $84.6 \%$ middle

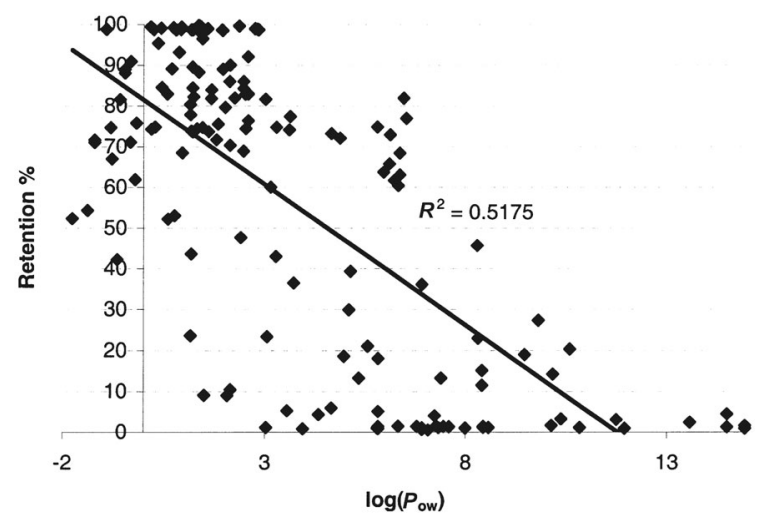

Figure 10. The dependence between the retention of smoke components by the human subjects and the partition coefficients $\log \left(P_{\text {ow }}\right)$ of several compounds from smoke

point), which is in good agreement with the results reported in the literature (15). Also, the results for phenol in this report show a retention between $91 \%$ and $99 \%(95.6 \%$ middle point), which is in good agreement with the value of $100 \%$ reported in the literature (20). Excellent agreement was also obtained for the retention of triacetin with $98.7 \%$ as compared to the reported value of $99 \pm 0.2 \%$ (20), propylene glycol with $98.9 \%$ as compared to $99 \pm 0.4 \%$ (20), pyridinol with $95.5 \%$ as compared to $94 \pm 5 \%$ (20), and for hydroquinone with $82.9 \%$ middle point retention as compared to reported $87 \pm 10 \%$ (20). Disagreement with the data from the literature was noticed only for neophytadiene, which was found in this study to be retained at a level of $45.7 \%$ compared to the reported $92 \pm 6 \%$ (20).

The study clearly shows that the retention of different compounds from cigarette smoke by human subjects differs from compound to compound. Although considerable variability was seen between the smokers, the same trend was found for all eight subjects. An attempt has been made to find similarity between the human retention of smoke components and the compounds retention in a chromatographic column. The separation in the chromatographic column is based on the compound distribution between the mobile phase and the stationary phase. The retention time on a DB-5 column (which is a dimethylpolysiloxane with $5 \%$ phenylpolysiloxane units) depends mainly on the boiling point of the compounds, and indirectly on the polarity of each compound (which affects the boiling point). The analogy between the retention of smoke components by the human subject and the chromatographic retention time is shown in Figure 9. A modification of the chromatographic retention times was performed to render all compounds as eluting at the same temperature (35). The graph from Figure 9 shows only a modest linear correlation $\left(R^{2}=0.5670\right)$.

The second attempt was made to correlate the human retention efficiency of individual compounds to their partition coefficient between octanol and water $\left(P_{\text {ow }}\right)$. The $\log \left(P_{\text {ow }}\right)$ values were either obtained from the literature (36) or calculated $(37,38)$. The graph showing the dependence of the retention on $\log \left(P_{\text {ow }}\right)$ is given in Figure 10. The linear correlation in this case is even weaker $\left(R^{2}=0.5175\right)$ than that on retention times. These results indicated that human retention of smoke components is not a simple distribution process, but a complex one, depending on the nature of the 
compounds and possibly on their concentration in smoke. The study of specific group of compounds with a larger number of subjects would generate more precise information on exhaled mainstream smoke composition.

\section{CONCLUSIONS}

A study has been performed to evaluate the retention of 160 compounds from mainstream cigarette smoke by eight human subjects, each smoking three cigarettes. The study showed that the retention of different compounds from cigarette smoke differs from compound to compound in a range from $5-10 \%$ to $90-100 \%$. About one third of the evaluated compounds, including molecules with lower molecular weight and relatively good solubility in water were retained more than $66 \%$. Another third of the measured compounds, which are found in the middle retention time range for a slightly polar chromatographic column are retained between $33 \%$ and $66 \%$. The last group which has even longer retention times in the chromatographic column consists mainly of long-chain hydrocarbons and sterol-type compounds. This group of compounds was retained much less by the smokers. An attempt was made to verify whether or not the retention of compounds by the smoker is analogous to a distribution process. Only weak correlations were obtained between the human retention and octanol/water partition coefficients or between the human retention and the chromatographic retention times of individual compounds.

\section{REFERENCES}

1. Lehmann, K.B.: Untersuchungen im Rauche des Tabaks [Investigation of the smoke from tobacco]; München med. Wochenschrift LV (1908) 723-725.

2. Isaac, R.F. and M.J. Rand: Cigarette smoking and plasma levels of nicotine; Nature 236 (1972) 308-310.

3. McAughey, J.J., D.K. Knight, A. Black, and C.J. Dickens: Environmental tobacco smoke retention in humans from measurements of exhaled smoke composition; Inhal. Toxicol. 6 (1994) 615-631.

4. Armitage, A.K., C.T. Dollery, C.F. George, T.H. Houseman, P.J. Lewis, and D.M. Turner: Absorbtion and metabolism of nicotine from cigarettes; Brit. Med. J. 4 (1975) 313-316.

5. Gori, G.B. and N.L. Benowitz, and C.J. Lynch: Mouth versus deep airways absorption of nicotine in cigarette smokers; Pharmacol. Biochem. Behav. 25 (1986) 1181-1184.

6. Armitage, A.K., M. Dixon, B.E. Frost, D.C. Mariner, and N.M. Sinclair: The effect of tobacco blend additives on the retention of nicotine and solanesol in the human respiratory tract and on subsequent plasma nicotine concentrations during cigarette smoking; Chem. Res. Toxicol. 17 (2004) 537-544.

7. Armitage, A.K., M. Dixon, B.E. Frost, D.C. Mariner, and N.M. Sinclair: The effect of inhalation volume and breath-hold duration on the retention of nicotine and solanesol in the human respiratory tract and on subsequent plasma nicotine concentrations during cigarette smoking; Beitr. Tabakforsch. Int. 21 (2004) 240-249.
8. Lehmann, K.B.: Chemische und toxikologische Untersuchung des Tabaks, des Tabakrauchs und des Tabakrauchens [Chemical and toxicological study on tobacco, tobacco smoke and tobacco smoking]; Arch. Hyg. 68 (1909) 321-420.

9. Broday, D.M. and P.G. Georgopoulos: Growth and deposition of hygroscopic particulate matter in the human lung; Aerosol. Sci. Tech. 34 (2001) 144-159.

10. Davies, C.N.: Deposition of inhaled particles in man; Chemistry and Industry (1974) 441-444.

11. Robinson, R.J. and C.P. Yu: Deposition of cigarette smoke particles in the human respiratory tract; Aerosol. Sci. Tech. 34 (2001) 202-215.

12. Hinds, W., M.W. First, G.L. Huber, and J.W. Shea: A method for measuring the deposition of cigarette smoke during smoking; Am. Ind. Hyg. Assoc. J. 44 (1983) 113-118.

13. Dalhamn, T., M-L. Edfors, and R. Rylander: Mouth absorption of various compounds in cigarette smoke; Arch. Environ. Health. 16 (1968) 831-835.

14. Dalhamn, T., M-L. Edfors, and R. Rylander: Retention of cigarette smoke components in human lungs; Arch. Environ. Health. 17 (1968) 746-748.

15. Baker, R.R. and M. Dixon: The retention of tobacco smoke constituents in the human respiratory tract; Inhal. Toxicol. 18 (2006) 255-294.

16. Laskowski, K.: Components of tobacco smoke and their absorption in the respiratory system of the smoker; Rocz. Państw. Zak. Hig. [Ann. Natl. Inst. Hyg.] 2 (1951) 139-160.

17. Haagen-Smit, A.J., M.F. Brunelle, and J. Hara: Nitrogen oxide content of smokes from different types of tobacco; A. M. A. Arch. Ind. Health 20 (1959) 399-400.

18. Egle, J.L. Jr: Retention of inhaled acetaldehyde in man; J. Pharmacol. Experim. Therapeutics 174 (1970) 14-19.

19. Deliconstantinos, G., V. Villiotou, and J.C. Stavrides: Scavenging effects of hemoglobin and related heme containing compounds on nitric oxide, reactive oxidants and carcinogenic nitroso compounds of cigarette smoke. A new method for protection against the dangerous cigarette constituents; Anticancer Res. 14 (1995) 2717-2726.

20. Ingebrethsen, B.J.: The physical properties of mainstream cigarette smoke and their relationship to deposition in the respiratory tract; in: Extrapolation of dosimetric relationships for inhaled particles and gases, edited by J.D. Crapo, E.D. Smolko, F.J. Miller, J.A. Graham, and A.W. Hayes, Chap. 12, New York, NY, Academic Press, 1989, pp. 125-141.

21. Gordon, S.M., L.A. Wallace, M.C. Brinkman, P.J. Callahan, and D.V. Kenny: Volatile organic compounds as breath biomarkers for active and passive smoking; Environ. Health Perspect. 110 (2002) 689-698.

22. Chaudhury, R., E. Levingston, L. Thomson, K. MacLeod, C. McSharry, J. Hossein, A. McKay, and N.C. Thomson: The effect of cigarette smoking on exhaled breath condensate prostaglandin E2 levels in asthma; American Thoracic Society/American Lung Association (ATS/ALA) Meeting Abstracts, Atlanta, May 18-23, 2002.

23. Garey, K.W., M. Neuhauser, M.M. Rafice, A.L. Robbins, L.H. Danziger, and I. Rubinstein: Protein, nitrate/nitrite, and cytokine concentration in exhaled breath condensate of young smokers; Amer. J. Respir. Critical Care Med. 161 (2000) A175. 
24. Chaudhury, R., E. Levingston, L. Thomson, C. McSharry, K. MacLeod, J. Hossein, A. McKay, and N.C. Thomson: Nitrite levels in the breath condensate of smoking asthmatics; American Thoracic Society/American Lung Association (ATS/ALA) Meeting Abstracts, Atlanta, May 18-23, 2002.

25. Corradi, M., I. Rubinstein, R. Andreoli, P. Manini, A. Caglieri, D. Poli, R. Alinovi, and A. Mutti: Aldehydes in exhaled breath condensate of patients with chronic obstructive pulmonary disease; Amer. J. Respir. Critical Care Med. 167 (2003) 1380-1386.

26. Risby, T.H.: Further discussion on breath condensate analysis; Amer. J. Respiratory and Critical Care Med. 167 (2003) 1301-1302.

27. Doyen, K., M. Carey, R.S.T. Linforth, M. Marin, and A.J. Taylor: Volatile release from an emulsion headspace and in-mouth studies; J. Agric. Food Chem. 49 (2001) 804-810.

28. Scheideler, L., H.G. Manke, U. Schwulera, O. Inacker, and H. Hammerle: Detection of nonvolatile macromolecules in breath, a possible diagnostic tool? Amer. Rev. Respir. Dis. 148 (1993) 778-784.

29. Holzer, G.J., Oro, and W. Bertsch: Gas chromatographic-mass spectrometric evaluation of exhaled tobacco smoke; J. Chromatogr. 126 (1976) 771-785.

30. Pillsbury, H.C., C.C. Bright, K.J. O'Connor, and F.H. Irish: Tar and nicotine in cigarette smoke; J. Assoc. Off. Anal. Chem. 52, (1969) 458-462.

31. ISO 10315: Cigarettes - determination of nicotine in smoke condensates - gas chromatographic method; International Organization for Standardization, Geneva, Switzerland, First Edition 1991-08-01, 1991 (E).

32. St.Charles, F.K.: A robust method for determining consumer smoked cigarette yields from filter analytical data; $55^{\text {th }}$ Tobacco Science Research Conference, Program Booklet and Abstracts, Vol. 55, Paper No. 92, 2001, pp. 73-74.
33. Bodnar, J.A., T.J. Collins, S.M. DeBusk, and M.F. Borgerding: Estimation of 'tar' and nicotine yields from individual cigarettes based on filter analysis after smoking; 58 ${ }^{\text {th }}$ Tobacco Science Research Conference, Program Booklet and Abstracts, Vol.58, Paper No. 8, 2004, p 25.

34. Borgerding, M.F., J.A. Bodnar, and D.E. Wingate, (Ed.): The 1999 Massachusetts benchmark study, final report (July 24, 2000), Vol. 4; R. J. Reynolds Tobacco Company, Winston-Salem, 2000.

35. Moldoveanu, S.C. and V. David: Sample preparation in chromatography; Elsevier, Amsterdam, 2002, pp. 58-60.

36. Hansch, C., A. Leo, and D. Hoekman: Exploring QSAR, hydrophobic, electronic and steric constants; ACS Professional Reference Book, Washington, DC 1995.

37. Broto, P., G. Moreau, and C. Vandyke: Molecular structure, perception, autocorrelation descriptor and SAR studies. System atomic contributions for the calculation of the $n$-octanol/water partition coefficients; Eur. J. Med. Chem. Chim. Theor. 19 (1984) 71-78.

38. Viswanadhan, V.N., A.K. Ghose, G.R. Ravankar, and R.K. Robins: Atomic physicochemical parameters for three-dimensional structure-directed quantitative structure-activity relationship IV; additional parameters for hydrophobic and dispersive interactions and their application for an automated superposition of certain naturally occurring nucleoside antibiotics; J Chem. Inf. Comput. Sci. 29 (1989) 163-172.

Address for correspondence:

Serban Moldoveanu

R.J. Reynolds Tobacco Co.

950 Reynolds Boulevard

Winston-Salem, NC 27105

E-mail:moldovs@rjrt.com 